\title{
Biochemical properties of free and immobilized Candida viswanathii lipase on octyl-agarose support: Hydrolysis of triacylglycerol and soy lecithin
}

\author{
Alex Fernando de Almeida ${ }^{\mathrm{a}}$, César Rafael Fanchini Terrasan ${ }^{\mathrm{b}}$, Cárol Cabral Terrone ${ }^{\mathrm{b}}$, \\ Sâmia Maria Tauk-Tornisielo ${ }^{\mathrm{c}}$, Eleonora Cano Carmona ${ }^{\mathrm{b}, *}$ \\ a Bioprocess Engineering and Biotechnology, Federal University of Tocantins - UFT, Rua Badejós, Chácaras 69/72, Zona Rural, Gurupi, Tocantins, 77402-970, Brazil \\ b Biochemistry and Microbiology Department, Bioscience Institute, São Paulo State University, IB/UNESP, Av. 24-A, 1515, Bela Vista, Rio Claro, São Paulo, 13506-900, \\ Brazil

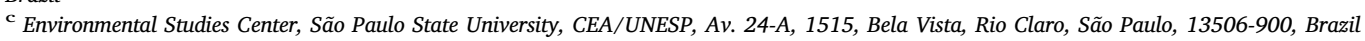

\section{A R T I C L E I N F O}

\section{Keywords:}

Triacylglycerol acyl hydrolase

Candida viswanathii

Enzyme purification

Enzyme characterization

Enzyme immobilization

Enzyme stabilization

\begin{abstract}
A B S T R A C T
Microbial lipases are important enzymes in food and pharmaceutical industries. In this work, a Candida viswanathii lipase was purified by hydrophobic interaction chromatography on octyl Sepharose. The purification presented $78.4 \%$ yield and the enzyme was 8.7 -fold purified, with specific activity $700.4 \mathrm{U} / \mathrm{mg}$ protein and $69 \mathrm{kDa}$ molecular weight. Immobilization of the enzyme on the same support presented $72.5 \%$ yield and a derivative with 101\% expressed activity (109.2 U/g support), indicating hyperactivation of the enzyme. Optimal activity for both free and immobilized lipase was observed at $\mathrm{pH} 4.0$ and $45^{\circ} \mathrm{C}$. The free and immobilized lipase showed broad-range stability from acid to neutral $\mathrm{pH}$, and apparent activation and stability on organic solvents. The derivative was 60-fold thermostabilized in relation to the free enzyme and fully retained its activity after four cycles of $p$-nitrophenyl palmitate hydrolysis. Slight activation was observed with dithiothreitol and $\beta$ mercaptoethanol. The free and immobilized lipase efficiently hydrolyzed monoesters, simple and mixed long chain triacylglycerols, as well as soy lecithin. The activity and stability in acid $\mathrm{pH}$, the organic solvent tolerance and the lecithin hydrolysis indicate high potential application of the enzyme and its derivative in textile, food and pharma industries and for chemical synthesis.
\end{abstract}

\section{Introduction}

Microbial lipases are excellent biocatalysts with important properties such as high specificity and selectivity, promoting reactions under mild conditions [1]. These enzymes are used in numerous industrial applications, including detergent formulation for the degradation of oils and fats, synthesis of pharmaceuticals and esters responsible for flavor and taste, as well as in cosmetics [2]. Lipases used in processes such as biodiesel production, oil and fats hydrolysis, effluent treatment and detergent production may be used as heterogeneous or partially purified mixtures, while food, pharmaceutical and cosmetic industries require purified preparations [3].

Lipases (triacylglycerol acyl hydrolases, E.C. 3.1.1.3) naturally catalyze the hydrolysis of ester bonds from long-chain triacylglycerols in organic-aqueous interfaces by a peculiar mechanism, the so-called interfacial activation. In homogenous media, most lipases have their active center covered by a polypeptide chain called lid, which isolate the molecule from the reaction medium (closed form); in the presence of hydrophobic surfaces, however, the enzyme becomes adsorbed on it, changing the structure to the open form in which the active center become fully exposed, allowing the lipases to hydrolyze drops of oils [4]. Their physiological role is to catalyze hydrolysis and sequential synthesis of triacylglycerols, providing diacylglycerol, monoacylglycerol, free fatty acids and glycerol [5]. The equilibrium displacement towards hydrolysis or synthesis is controlled by the amount of water in the reaction medium, i.e., in water presence hydrolysis is the main reaction, while esterification occurs in the presence of organic solvents [6].

Apart from the inherent solubility of the proteins, lipases usually present low stability even at mild conditions, and the high cost for a single use limits therefore its industrial application. Enzyme immobilization may provide an effective method to circumvent these issues not only by improving catalytic properties and operational stability of enzymes, but also by facilitating multiple reuse and ease separation of the biocatalyst, enabling continuous industrial operation [7]. The choice of an immobilization technique for successful lipase

\footnotetext{
* Corresponding author.

E-mail address: ecarmona@rc.unesp.br (E.C. Carmona).

URL: http://mailto:ecarmona@rc.unesp.br (E.C. Carmona).
} 
immobilization should consider several concerns: the enzyme should be stable during the immobilization process; the procedure should be robust, reproducible, cost-effective and scalable; the materials and equipment should apply to food grade regulations if the immobilized lipase is intended to be used in food applications; the immobilization should preferably stabilize the enzyme in terms of temperature, $\mathrm{pH}$, organic solvents and operational reusability; and the biocatalyst should be physically robust and rather applicable in both batch and fixed bed processes [8].

Immobilization of lipases using interfacial adsorption on hydrophobic supports has been proposed as a simple method to prepare robust derivatives $[9,10]$. This method take into account a simple adaptation of the Michaelis-Menten-Henri kinetic model to the interfacial hydrolysis of oil drops, in which the first step correspond to the fixation of a water-soluble enzyme to the lipid-water interface via a reversible adsorption-desorption mechanism. The penetration/adsorption step lead to a more favorable energy state of the enzyme present at the interface, which binds to substrate molecule, resulting in the formation and subsequent dissociation of the enzyme-substrate complex [11,12]. By using hydrophobic supports that resembles the surface of natural substrates and very low ionic strength, lipases can be selectively immobilized on the support. This mechanism proved to be advantageous allowing immobilization of lipases via an "affinity-like" strategy that can also significantly enhances enzyme activity [10]. Manoel et al. [4] immobilized lipases from Thermomyces lanuginosus and Pseudomonas cepacea on octyl and cyanogen bromide agarose, confirming that the octyl agarose derivatives present their open form stabilized while the covalent preparation maintains the closing/opening equilibrium.

Lipases from the Candida genus, including those from Candida rugosa, Candida antarctica, Candida cylindracea, present molecular weight ranging from 33 to $64 \mathrm{kDa}$ and multiple isoforms [13-16]. These lipases normally show similar biochemical properties such as optimal activity in the $\mathrm{pH}$ range $7.0-8.0$ and at $30-60{ }^{\circ} \mathrm{C}$ [13-16]. Lipases from $C$. antarctica (CALB), C. rugosa and Mucor miehei were immobilized by adsorption on hydrophobic supports as a quick and inexpensive alternative to obtain purified samples, rendering high yield and, in some cases, activation of the enzyme [17]. Adsorption technique allows the regeneration of the support, easing enzyme immobilization, and reducing costs and industrial wastes [18].

A Candida viswanathii strain grows and efficiently produces lipase when cultivated in liquid medium containing natural triacylglycerols, under agitation and temperature control $[19,20]$. Partial characterization showed that the crude enzyme is an acid and organic solvent tolerant lipase that could potentially be applied in bioprocesses. The aims of this study were to purify and immobilize this lipase on hydrophobic support. The purified free-enzyme and the derivative were biochemically characterized and its potential for hydrolyzing triacylglycerol and soy lecithin were also evaluated.

\section{Materials and methods}

\subsection{Strain and maintenance}

C. viswanathii strain is available in the Culture Collection of the Environmental Studies Center - CEA/UNESP, Brazil. C. viswanathii was routinely cultivated on malt extract agar (MEA) for 3 days at $28^{\circ} \mathrm{C}$ and then stored at $4{ }^{\circ} \mathrm{C}$. Cultures were also performed in MEA slants at the same conditions for inoculum preparation.

\subsection{Liquid culture and protein extract preparation}

Modified Vogel liquid medium [21] was prepared using 1.5\% (w/v) olive oil and $0.2 \%(\mathrm{w} / \mathrm{v})$ yeast extract as carbon and nitrogen sources, respectively. Erlenmeyer flasks $(125 \mathrm{~mL})$ containing $25 \mathrm{~mL}$ of the medium were inoculated with $1.0 \mathrm{~mL}$ of cells suspension $\left(1 \times 10^{7}\right.$ cells/mL). Cultivation was carried out at $27.5^{\circ} \mathrm{C}, 210 \mathrm{rpm}$ for $72 \mathrm{~h}$ [20].
Biomass was removed by filtration using $0.45 \mu \mathrm{m}$ cut-off cellulose acetate membrane followed by centrifugation $\left(8500 \mathrm{~g}, 20 \mathrm{~min}, 4^{\circ} \mathrm{C}\right)$. The supernatant was used as source of lipase for purification and immobilization experiments.

\subsection{Lipase activity}

Lipase activity was assayed with $p$-nitrophenyl palmitate (p-NPP) (Sigma-Aldrich) as substrate [20]. p-NPP was initially dissolved in $0.5 \mathrm{~mL}$ of dimethyl sulfoxide (DMSO), then diluted to $0.5 \mathrm{mM}$ with McIlvaine buffer pH 3.5 containing $0.5 \%(w / v)$ Triton X-100. The hydrolysis of $p$-NPP was determined discontinuously by measuring the released $p$-nitrophenolate ( $p$-NP) at $40{ }^{\circ} \mathrm{C}$. After 5 min pre-incubation of $0.9 \mathrm{~mL}$ of the substrate solution in a water bath, the reaction was started by adding $0.1 \mathrm{~mL}$ of appropriately diluted enzyme solution. The reaction was stopped after 1 and $2 \mathrm{~min}$ by heat shock $\left(1 \mathrm{~min}, 90^{\circ} \mathrm{C}\right.$ ), followed by the addition of $1 \mathrm{~mL}$ of saturated sodium tetraborate solution. The absorbance was read at $405 \mathrm{~nm}$ and the activity was determined using a $p$-NP standard curve $\left(\varepsilon=1.8 \times 10^{4} \mathrm{M}^{-1} \mathrm{~cm}^{-1}\right)$. Controls were prepared without enzyme. One enzyme unit (U) was defined as the amount of enzyme that releases $1 \mu$ mol of product per min.

\subsection{Protein}

Protein was determined with bicinchoninic acid (BCA) [22], using bovine serum albumin as standard. Protein was followed by reading absorbance at $280 \mathrm{~nm}$ during purification chromatography.

\subsection{Purification}

The crude extract was previously dialyzed against $0.05 \mathrm{M}$ ammonium acetate buffer $\mathrm{pH} 6.9$ ( $8 \mathrm{~h}, 3$ changes, $\left.4{ }^{\circ} \mathrm{C}\right)$. The dialyzed extract was applied to a hydrophobic octyl column (Hiprep $^{\mathrm{TM}} 16 / 10$ Octyl Sepharose FF fast flow, GE Healthcare) previously equilibrated in the same buffer; at $2 \mathrm{~mL} / \mathrm{min}$ flow rate. The column was washed with $50 \mathrm{~mL}$ of the same buffer and $3.0 \mathrm{~mL}$ fractions were collected. Elution of bounds proteins was performed with $100 \mathrm{~mL}$ of a $0.0-1.0 \%(\mathrm{w} / \mathrm{v})$ Triton X-100 linear gradient prepared in the same buffer. Fractions with lipase activity were pooled and sample purity was evaluated by SDSPAGE. All purification procedures were carried out at $4{ }^{\circ} \mathrm{C}$.

\subsection{Immobilization}

The crude extract was previously dialyzed against $0.05 \mathrm{M}$ ammonium acetate buffer $\mathrm{pH} 6.9$ ( $8 \mathrm{~h}, 3$ changes, $\left.4{ }^{\circ} \mathrm{C}\right)$. The dialyzed extract was applied to $10 \mathrm{~g}$ of octyl Sepharose Fast Flow (GE Healthcare) previously packed in a column $(1.5 \times 12.0 \mathrm{~cm})$ and equilibrated in the same buffer; at $2 \mathrm{~mL} / \mathrm{min}$ flow rate. The column was washed with $50 \mathrm{~mL}$ of this buffer and the resin containing the immobilized lipase (derivative) was manually collected and stored at $10^{\circ} \mathrm{C}$.

Immobilization efficiency was presented by the efficiency factor $(\eta)$ : $\eta=\frac{V_{\text {immobilized }}}{V_{\text {free }}}$

where, $\mathrm{V}_{\text {immobilezed }}$ is maximum reaction velocity of the derivative and $\mathrm{V}_{\text {free }}$ is maximum reaction velocity of the free enzyme.

\subsection{Derivative reuse}

Successive cycles of $0.5 \mathrm{mM}$-NPP hydrolysis were carried out in batch mode using McIlvaine buffer $\mathrm{pH} 3.5$ at $40{ }^{\circ} \mathrm{C}$. After each 1 mincycle, the immobilized lipase was recovered from the reaction medium by centrifugation $\left(8000 \mathrm{~g}, 10 \mathrm{~min}, 4^{\circ} \mathrm{C}\right)$ and abundantly washed with $0.05 \mathrm{M}$ ammonium acetate buffer $\mathrm{pH}$ 6.9. Then, fresh reaction medium 
was added for the next run. Enzymatic activity in the derivative was determined at the end of each run and expressed in relation to the initial activity.

\subsection{Enzyme characterization}

\subsubsection{Sample treatment and electrophoresis}

The purified enzyme was previously treated with Calbiosorb ${ }^{\mathrm{TM}}$ adsorbent resin (Calbiochem, San Diego, USA) to remove Triton X-100. The resin was equilibrated in $0.05 \mathrm{M}$ ammonium acetate buffer $\mathrm{pH} 6.9$ and loaded to the purified enzyme. Samples were incubated under slow stirring $\left(45 \mathrm{~min}, 10^{\circ} \mathrm{C}\right)$, centrifuged $\left(8500 \times g, 4{ }^{\circ} \mathrm{C}, 20 \mathrm{~min}\right)$ and the supernatant containing the enzyme was submitted to electrophoresis.

SDS-PAGE was performed using $10 \%(\mathrm{w} / \mathrm{v})$ polyacrylamide gels according to Hames [23]. Samples were previously treated with $8 \mathrm{M}$ urea, according to Lesuisse et al. [24]. Resolved protein bands were visualized after staining with $0.1 \%(\mathrm{w} / \mathrm{v})$ coomassie brilliant blue R250 in methanol, acetic acid and distilled water (4:1:5, v/v/v).

\subsubsection{Optimum $p H$ and stability to $p H$}

The activity of the free and immobilized lipase was measured at $40{ }^{\circ} \mathrm{C}$ in different $\mathrm{pH}$ values using $0.05 \mathrm{M}$ glycine- $\mathrm{HCl}$ buffer for $\mathrm{pH}$ from 2.0 to 3.0 and McIlvaine buffer from pH 3.0-8.0. Enzyme stability was carried out with the same buffers and also with $0.05 \mathrm{M}$ glycine$\mathrm{NaOH}$ from $\mathrm{pH}$ 8.0-10.0. Enzyme samples were 1:2 (v/v) diluted in each buffer and incubated at $10{ }^{\circ} \mathrm{C}$. After $24 \mathrm{~h}$, activity was assayed and expressed in relation to the initial activity.

\subsubsection{Optimum temperature and thermal stability}

The optimum temperature was determined by carrying out the enzymatic reactions at $25-60^{\circ} \mathrm{C}$, in McIlvaine buffer $\mathrm{pH} 4.0$. For thermal stability, the free enzyme was incubated at 30,40 and $45^{\circ} \mathrm{C}$, and the immobilized enzyme was incubated at $40,45,50$ and $60{ }^{\circ} \mathrm{C}$ in the same buffer. Free enzyme was incubated up to $60 \mathrm{~min}$ and derivative was incubated up to $180 \mathrm{~min}$. Samples were collected in several time intervals and the activity was analyzed in McIlvaine buffer $\mathrm{pH} 4.0$ at $45{ }^{\circ} \mathrm{C}$. Half-lives were calculated by the ratio $\ln 2 / \mathrm{K}_{\mathrm{d}}$. The constant of thermal inactivation $\left(\mathrm{K}_{\mathrm{d}}\right)$ was determined by the equation: $\ln A=\ln A_{O}-\mathrm{K}_{\mathrm{d}} \mathrm{x}$ t, where $A_{O}$ and $A$ are, respectively, the initial activity and the activity after time $\mathrm{t}(\mathrm{min})$. Stabilization was calculated as the ratio between half-lives of the immobilized and free lipase.

\subsubsection{Effect of chemical compounds on enzyme activity and stability}

The effect of metallic ions and other compounds on the free and immobilized lipase was evaluated at 2 and $10 \mathrm{mM}$. Samples were collected in several time intervals and the activity was assayed in McIlvaine buffer $\mathrm{pH} 4.0$ at $45{ }^{\circ} \mathrm{C}$. Half-lives were calculated by the ratio ln $2 / \mathrm{K}_{\mathrm{d}}$. The constant of inactivation $\left(\mathrm{K}_{\mathrm{d}}\right)$ was determined by the equation: $\ln A=\ln A_{O}-\mathrm{K}_{\mathrm{d}} \times \mathrm{t}$, where $A_{o}$ and $A$ are, respectively, the initial activity and the activity after time $\mathrm{t}(\mathrm{h})$.

\subsubsection{Effect of organic solvents on enzyme activity and stability}

The effect of organic solvents on the activity of the free and immobilized lipase was determined using $10 \%(\mathrm{v} / \mathrm{v})$ glycerol, DMSO, propylene glycol, methanol, acetonitrile, ethanol, acetone, 1-propanol, 2-propanol, $n$-butanol, toluene, xylol, $n$-hexane and isooctane in a reaction medium containing $0.5 \mathrm{mM} p$-NPP dissolved in McIlvaine buffer $\mathrm{pH} 4.0$ at $45^{\circ} \mathrm{C}$.

Stability of the free and immobilized lipase on organic solvents was evaluated using 10\% (v/v) glycerol, DMSO, propylene glycol, methanol, acetonitrile, ethanol, acetone, 1-propanol, 2-propanol, n-butanol, toluene, xylol, $n$-hexane and isooctane. Experiments were carried out in sealed flasks at $200 \mathrm{rpm}$ orbital agitation and $30^{\circ} \mathrm{C}$. Samples were withdrawn at several time intervals and the activity was analyzed in McIlvaine buffer $\mathrm{pH} 4.0$ at $45^{\circ} \mathrm{C}$. Half-lives were calculated by the ratio $\ln 2 / K_{d}$. The constant of inactivation $\left(K_{d}\right)$ was determined by the equation: $\ln A=\ln A_{O}-\mathrm{K}_{\mathrm{d}} \mathrm{x}$ t, where $A_{O}$ and $A$ are, respectively, the initial activity and the activity after time $\mathrm{t}(\mathrm{h})$.

\subsubsection{Specificity for substrate}

Specificity for substrate of the free and immobilized lipase was verified by using $0.5 \mathrm{mM} p$-nitrophenyl acetate, $p$-nitrophenyl butirate, $p$-nitrophenyl octanoate, $p$-nitrophenyl decanoate, $p$-nitrophenyl laurate, $p$-nitrophenyl myristate, $p$-nitrophenyl palmitate and $p$-nitrophenyl stearate on enzyme assays performed in McIlvaine buffer $\mathrm{pH}$ 4.0 at $45^{\circ} \mathrm{C}$.

Hydrolysis of tributirin, triolein, canola oil, corn oil, olive oil, soybean oil and sunflower oil and soy lecithin was developed at $40{ }^{\circ} \mathrm{C}$. Emulsion $(10 \%, \mathrm{w} / \mathrm{v})$ was carried out in Mcllvaine buffer $\mathrm{pH} 4.0$, containing $5 \%(\mathrm{w} / \mathrm{v})$ Triton X-100. The reaction was started by adding $1 \mathrm{~mL}$ of enzyme sample to $5 \mathrm{~mL}$ of this emulsion, and then it was maintained at $300 \mathrm{rpm}$ orbital agitation for $30 \mathrm{~min}$. The reaction was interrupted by adding $16 \mathrm{~mL}$ of an acetone:ethanol solution $(1: 1, \mathrm{v} / \mathrm{v})$ to the mixture. The released fatty acids were titrated to $\mathrm{pH} 11.0$ with $0.05 \mathrm{M} \mathrm{NaOH}$. One enzyme unit (U) was defined as the amount of enzyme that releases $1 \mu \mathrm{mol}$ of fatty acid per min. The results were expressed as percentage of hydrolyzed triolein.

\subsubsection{Kinetic parameters}

The activity of free and immobilized lipase was assayed with $p$-nitrophenyl palmitate at concentrations from 0.0 to $1.0 \mathrm{mM}$. The Michaelis-Menten constant $\left(K_{\mathrm{m}}\right)$ and maximum reaction velocity $\left(\mathrm{V}_{\max }\right)$ were estimated from the Lineweaver-Burk plot [25].

\section{Results and discussion}

\subsection{Purification, immobilization and reuse of $C$. viswanathii lipase}

The dialyzed extract was directly used as initial sample for purification of the $C$. viswanathii lipase by hydrophobic interaction chromatography. The adopted strategy did not request previous salt addition to the sample and under these conditions most of proteins did not bind to the resin. Accordingly, most of non-target proteins were washed, while no lipase was eluted from the column. Elution of bound proteins was performed with a Triton X-100 gradient (Fig. 1). Adsorbed proteins eluted with about $0.88 \%$ Triton X-100, which also absorbs at $280 \mathrm{~nm}$. Thus, fractions were also assayed for lipase activity and those with high activity were pooled. Part of the sample was treated to remove the detergent and applied to SDS-PAGE, which showed electrophoretic homogeneity with only one $69 \mathrm{kDa}$ band (Fig. 2). Samples of the crude and dialyzed filtrates were detergent free, while samples of the purified enzyme still contained Triton X-100, since Calbiosorb could not completely remove this detergent. The purified lipase presented slightly higher MW than the crude enzyme probably due to the presence of residual Triton X-100. Hughey et al. [26] also observed differences in MW of $r$-glutamyltranspeptidase samples treated with Triton X-100. According to these authors, estimation of the enzyme MW may be complicated by the presence of carbohydrates and binding sites, which interact with large amounts of charged detergents and therefore cause the abnormal protein migration in electrophoresis gels.

Following the proposed protocol, $C$. viswanathii lipase could be purified by a practical, fast and relatively inexpensive one-step procedure, which is very interesting for further process scale-up. The enzyme was 8.7 -fold purified, presenting specific activity of $700.4 \mathrm{U} / \mathrm{mg}$ of protein and the process presented $78.4 \%$ yield (Table 1 ). Attempts to determine native molecular mass by size exclusion chromatography on Sephadex G-100 and G-200 columns, even in the presence of urea or Triton-X100, were not successful because the enzyme was always eluted in the void volume (not shown), indicating the formation of soluble and catalytically active aggregates with MW higher than $600 \mathrm{kDa}$. Aggregation is commonly verified among lipase molecules and its occurrence is due to surface hydrophobicity. This phenomenon was 


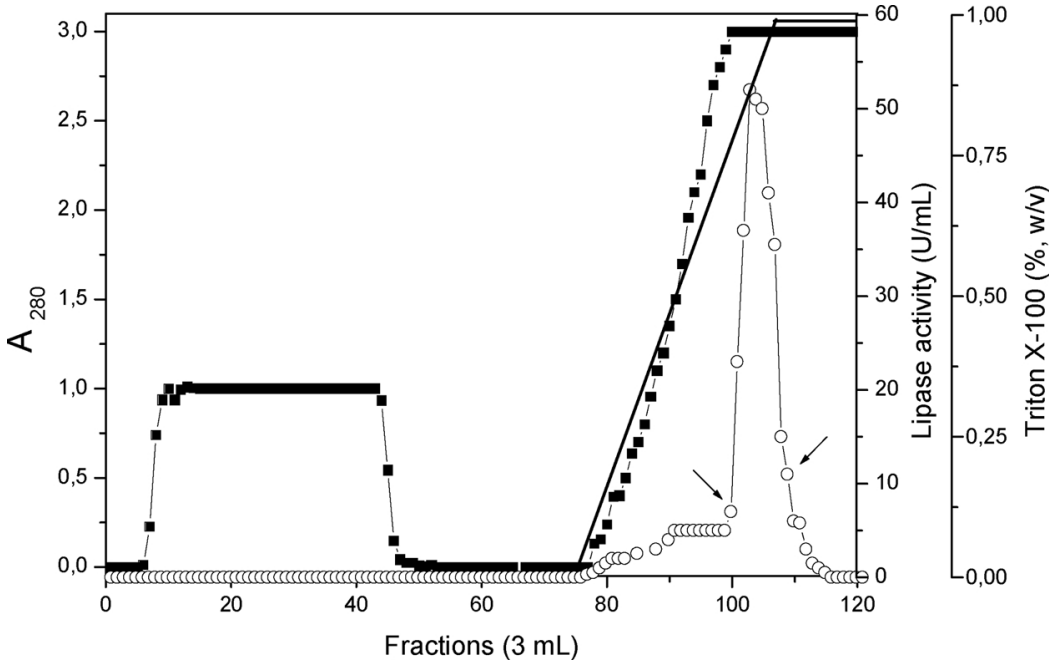

Fig. 1. Hydrophobic interaction chromatography profile of $C$. viswanathii lipase on octyl Sepharose. The column was equilibrated with $0.05 \mathrm{M}$ ammonium acetate buffer $\mathrm{pH} 6.9$ and eluted with Triton X-100 gradient using $2 \mathrm{~mL} / \mathrm{min}$ flow rate. ( $\square$ ) Absorbance $280 \mathrm{~nm}$; (O) lipase activity (U/mL); (-) Triton X-100 gradient; Arrows indicate the pooled fractions.

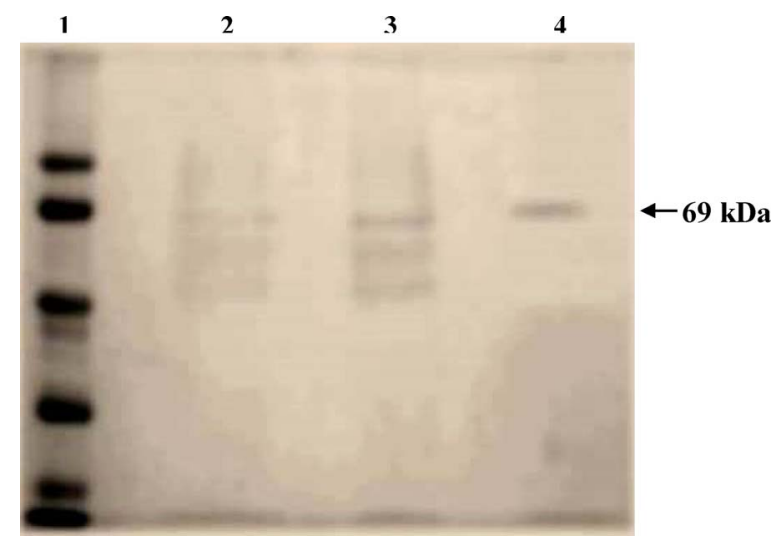

Fig. 2. Electrophoretic profile SDS-PAGE of C.viswanathii lipase. Column 1-standards: phosphorilase b (97.0 kDa), albumin bovine serum (66.0 kDa), ovoalbumin (45.0 kDa), carbonic anhydrase $(30.0 \mathrm{kDa})$, trypsin inhibitor $(20.1 \mathrm{kDa})$, and $\alpha$-lactalbumin (14.4 kDa); Column 2-crude filtrate; Column 3-dialyzed filtrate; Column 4-purified lipase.

previously reported for the lipases from C. rugosa, Mucor miehei, Humicola lanuginosa [17], and Pseudomonas fluorescens [27]. Aggregates of the $C$. rugosa lipase with different MW was clearly demonstrated by Liou et al. [28] that verified four proteins peaks of 440,240, 130 and $60 \mathrm{kDa}$ using a Sephadex G-200 column and only one $60 \mathrm{kDa}$ band by SDS-PAGE.

Considering that lipases immobilized on hydrophobic supports involve their open form, the chromatographic process was repeated in the same conditions but without elution of bound proteins. The process presented $72.5 \%$ yield and the derivative was obtained with $109.2 \mathrm{U} / \mathrm{g}$ support. The immobilization efficiency factor $\left(\eta=V_{\text {immobilized }} / V_{\text {free }}\right)$ was 1.01 for the $C$. viswanathii lipase. Guo et al. [29] immobilized $C$. cylindracea lipase on magnetic hydrophobic microspheres, and the efficiency factor was 1.50 when olive oil was used as substrate and 0.32 for $p$-nitrophenyl acetate as substrate.

Selective adsorption of lipases involves the hydrophobic areas surrounding the active center and the internal face of the lid, while other water soluble proteins usually do not adsorb on these supports under these mild conditions [10]. Bastida et al. [9] previously observed that the lipase from Rhizopus niveus is much faster immobilized on octyl agarose by decreasing ammonium sulfate concentration from $1 \mathrm{M}$ to $10 \mathrm{mM}$. This behavior was quite different from standard hydrophobic adsorption of proteins in which adsorption rate and yield strongly increase by increasing salt concentration. Manoel et al. [4] demonstrated that the hydrophobic adsorption of Pseudomonas cepacia and Thermomyces lanuginosus lipases in different ionic strength resulted in an immobilization via surface affinity adsorption involving the open form of the enzymes.

The stability of the immobilized lipase was evaluated during successive batches of p-NPP hydrolysis (Fig. 3). The derivative retained $100 \%$ of activity after 4 reuse cycles. After 6 and 7 cycles, the activity corresponded to 50 and $20 \%$ of the initial activity, respectively. The main reason for the loss of activity probably was the enzyme desorption from the support, since the reaction medium contained $0.5 \%$ Triton $\mathrm{X}$ 100. Palomo et al. [10] demonstrated that lipases from C. antarctica, $C$. rugosa and $M$. miehei were desorbed from octyl agarose supports by the addition of $1.0,0.5$ and $0.07 \%$ Triton X-100, respectively.

\subsection{Biochemical properties of free and immobilized C. viswanathii lipase}

\subsubsection{Effect of $p H$ on activity and stability}

When the activity of the free and immobilized lipase was evaluated in the $\mathrm{pH}$ range from 2.0 to 8.0 (Fig. 4a), both forms presented similar profiles with the highest activity at $\mathrm{pH} 4.0$. At $\mathrm{pH}$ from 2.0 to 3.0 the immobilized enzyme was more active presenting $55 \%$ of activity while the free enzyme presented $15-40 \%$ of activity. Free and immobilized enzyme showed 80 and $90 \%$ of activity at pH 3.5 and 4.5, respectively; and in the $\mathrm{pH}$ range $5.0-6.5$, the activity corresponded to $65 \%$ of the maximum. Above $\mathrm{pH} 6.5$ there was a decrease in the activity up to $\mathrm{pH}$ 8.0. The crude $C$. viswanathii lipase shows optimum activity in slightly more acid condition ( $\mathrm{pH}$ 3.5) compared to the free purified and immobilized lipase; and also, presents higher activity at $\mathrm{pH}$ from 2.0 to 3.0

Table 1

Purification of lipase from C. viswanathii.

\begin{tabular}{|c|c|c|c|c|c|}
\hline Step & Total activity (U) & Total protein (mg) & Specific activity ( $\mathrm{U}$ mg protein ${ }^{-1}$ ) & Yield (\%) & Purification (fold) \\
\hline Dialyzed filtrate & $1250.4 \pm 15.4$ & $15.6 \pm 1.2$ & $80.2 \pm 1.0$ & $100.0 \pm 1.8$ & 1.0 \\
\hline Octyl Sepharose & $980.6 \pm 7.4$ & $1.4 \pm 0.2$ & $700.4 \pm 4.2$ & $78.4 \pm 0.9$ & 8.7 \\
\hline
\end{tabular}

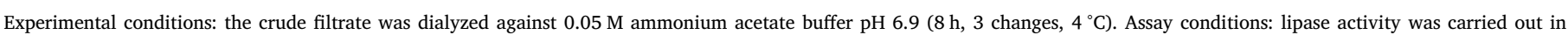
McIlvaine buffer $\mathrm{pH} 3.5$ at $40{ }^{\circ} \mathrm{C}$. 


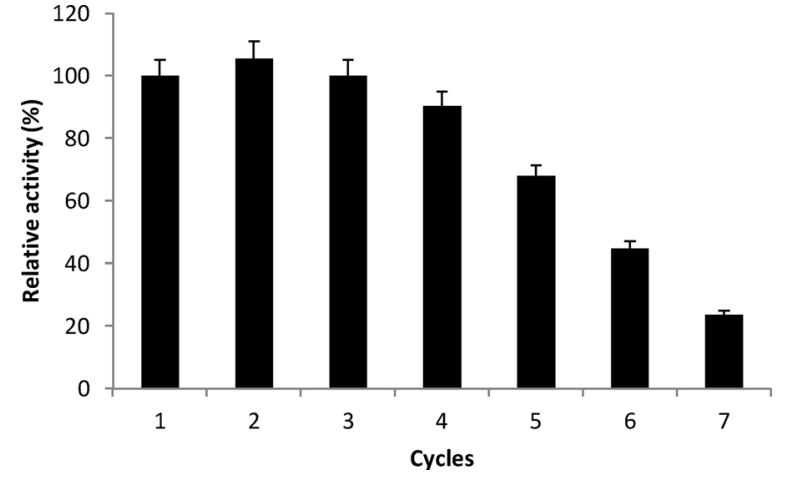

Fig. 3. Reusability of $C$. viswanathii lipase immobilized on octyl agarose. Lipase activity was determined with McIlvaine buffer $\mathrm{pH} 3.5$ at $40{ }^{\circ} \mathrm{C}$.
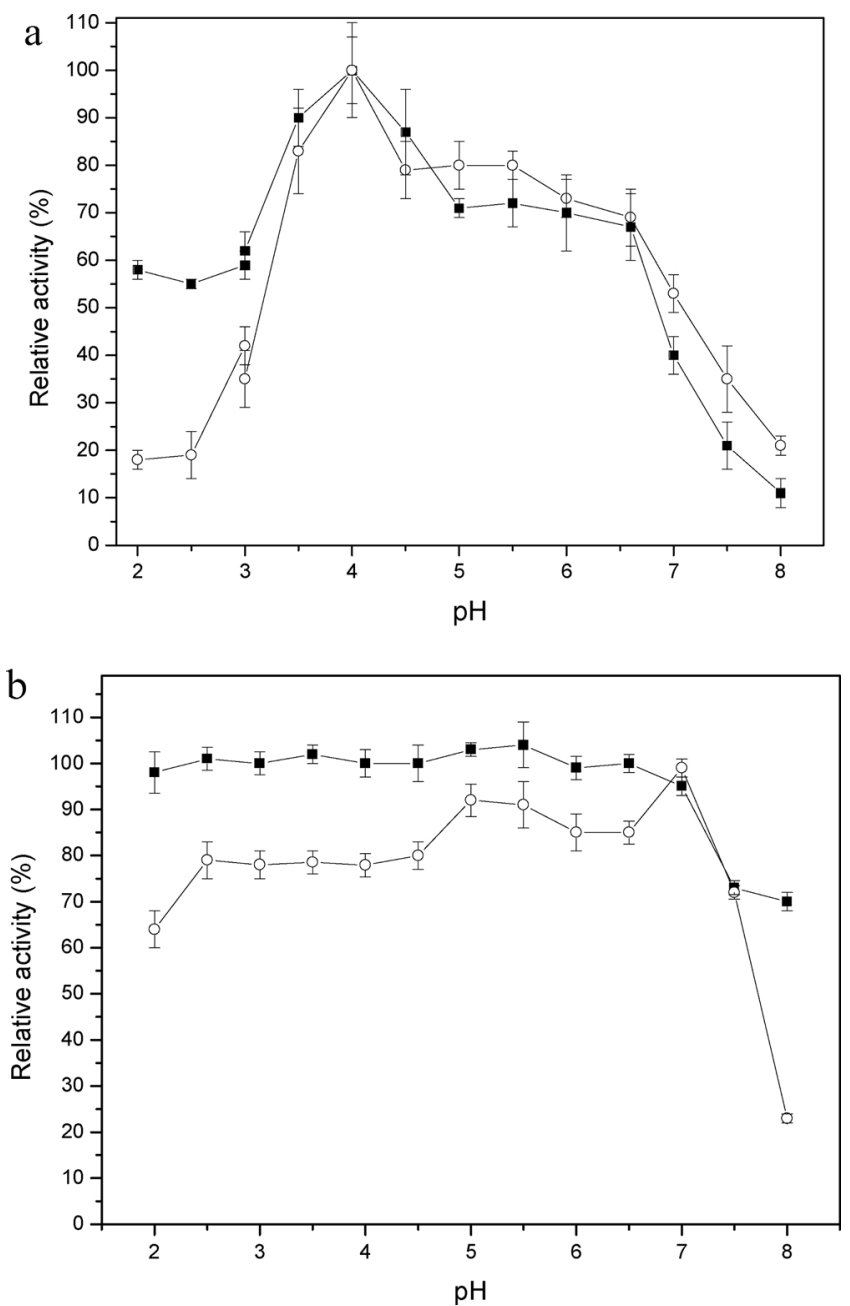

Fig. 4. Effect of $\mathrm{pH}$ on activity (a) and stability (b) of free and immobilized C. viswanathii lipase. (a) Activity was determined in $0.05 \mathrm{M}$ glycine- $\mathrm{HCl}$ buffer $\mathrm{pH}$ from 2.0 to 3.0 and McIlvaine buffer for $\mathrm{pH}$ from 3.0 to 8.0. (b) Lipase activity was determined in Mcllvaine buffer $\mathrm{pH} 4.0$ at $40{ }^{\circ} \mathrm{C}$. (O) free lipase, $(\boldsymbol{\square})$ immobilized lipase. Free lipase activity corresponded to $36.0 \mathrm{U} / \mathrm{mg}$ prot. and immobilized lipase corresponded to $38.0 \mathrm{U} / \mathrm{mg}$ prot.

(45-53\%, respectively) [20]. Besides, the present lipase differs from those of $C$. antarctica, C. rugosa, and C. cylindracea which are neutral or alkaline enzymes $[13,14]$.

During incubation at different $\mathrm{pH}$ (Fig. 4b), both lipase forms showed long-term stability in the $\mathrm{pH}$ range from 2.0 to 7.0 . Immobilized lipase retained more than $90 \%$ of activity in this $\mathrm{pH}$ range, while the free lipase maintained its activity between 60 and $90 \%$ from

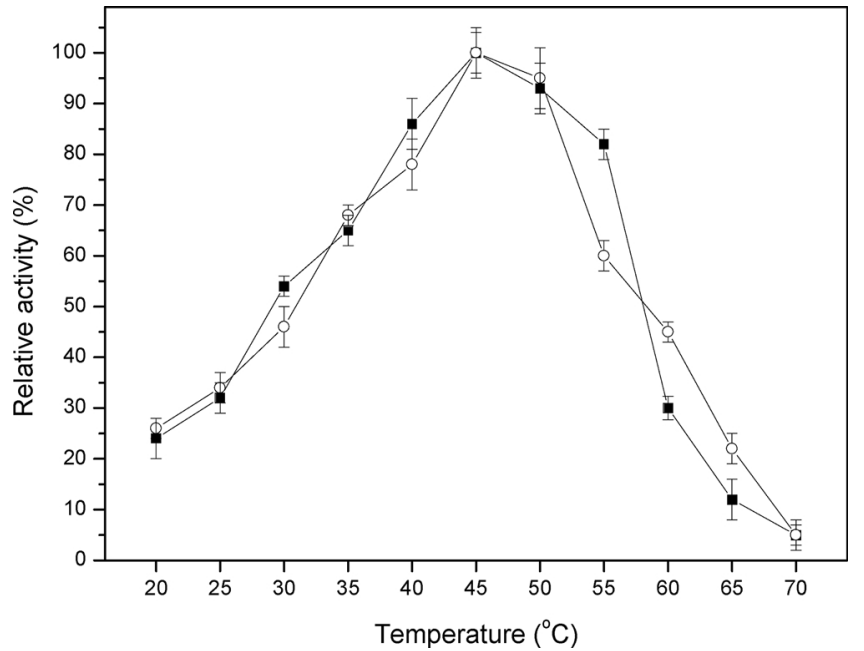

Fig. 5. Optimal temperature of free and immobilized C. viswanathii lipase. Activity was determined in McIlvaine buffer $\mathrm{pH}$ 4.0. (O) free lipase, $(\square)$ immobilized lipase. Free lipase activity corresponded to $36.0 \mathrm{U} / \mathrm{mg}$ prot. and immobilized lipase corresponded to $38.0 \mathrm{U} / \mathrm{mg}$ prot.

pH 2.0-7.5. Crude lipase from C. viswanathii presents different stability at $\mathrm{pH} 2.0$ and 2.5, in which the enzyme is completely inactivated [20]. The immobilized lipase retained $100 \%$ of its activity in this $\mathrm{pH}$ range; at $\mathrm{pH} 7.5$ and 8.0 more than $70 \%$ of activity was retained, indicating that the hydrophobic immobilization increased its stability to a wider $\mathrm{pH}$ range.

\subsubsection{Effect of temperature on activity and stability}

The effect of temperature on free and immobilized lipase activities is presented in Fig. 5. Maximal activities for both free and immobilized lipase were observed at $45^{\circ} \mathrm{C}$. The crude $C$. viswanathii lipase presents optimum activity at $40{ }^{\circ} \mathrm{C}$, and high activity is also observed at 45 and $50{ }^{\circ} \mathrm{C}$ with a sharp decrease at $60^{\circ} \mathrm{C}[20]$. The similarity in activity profiles for the free and immobilized enzyme indicated there were no significant changes in the conformation of the immobilized enzyme promoted by interactions with the support. Similar behavior is also found for C. rugosa lipase adsorbed on calcium carbonate matrix [30].

When thermal stability of the free and immobilized lipase was assayed in absence of substrate, the free enzyme maintained about $65 \%$ of activity up to $20 \mathrm{~min}$ at $30^{\circ} \mathrm{C}$, and the half-life was $27 \mathrm{~min}$. The halflives of the free enzyme at 40 and $45{ }^{\circ} \mathrm{C}$ were 5.0 and $4.5 \mathrm{~min}$, respectively (Fig. 6a). Immobilized lipase showed higher thermal stability than the free enzyme, maintaining more than $70 \%$ of activity even after $180 \mathrm{~min}$ both at 40 and $45{ }^{\circ} \mathrm{C}$. At $50{ }^{\circ} \mathrm{C}$, the enzyme retained above $80 \%$ after $60 \mathrm{~min}$ and more than $70 \%$ of activity up to $120 \mathrm{~min}$, presenting half-life of $175 \mathrm{~min}$. At $60{ }^{\circ} \mathrm{C}$, the immobilized lipase presented half-life of $7.5 \mathrm{~min}$ (Fig. 6b). Immobilization by interfacial activation on hydrophobic supports was very suitable to stabilize the $C$. viswanathii lipase, i.e. the immobilized enzyme was 60 - and 62.2-fold stabilized in relation to the free enzyme at 40 and $45^{\circ} \mathrm{C}$, respectively. The increased thermostability of the immobilized lipase suggests that the hydrophobic immobilization helps preserving enzyme structure from conformational changes caused by temperature, i.e. immobilization fixes the enzyme in such a way that reduces the susceptibility to denaturation by heat. Ours results is consistent with others dealing with lipase immobilization on hydrophobic supports. Lipases from $C$. rugosa and M. miehei hydrophobically immobilized on octadecyl-Sepabeads retain, respectively, 100 and $60 \%$ of activity after $2 \mathrm{~h}$ [10]. Wilson et al. [31] reported a 23fold increase on thermal stability of the lipase from Alcaligenes sp. immobilized on octadecyl-Sepabeads. Fernandez-Lorente et al. [32] evaluated the thermal stability of Bacillus thermocatenulatus lipase immobilized on octyl Sepharose, butyl Sepharose, butyl Toyopearl or hexyl Toyopearl. The octyl Sepharose derivative was the most stable 

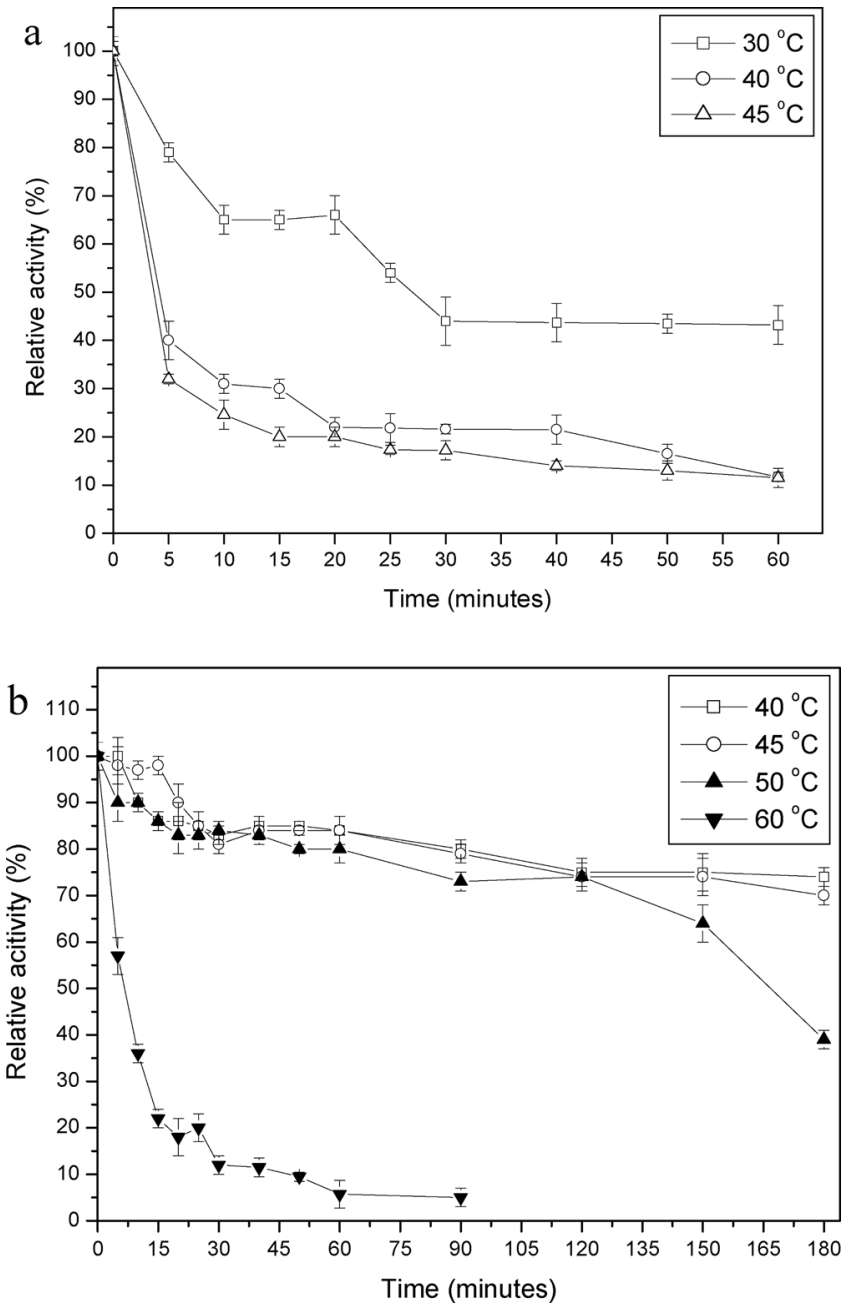

Fig. 6. Thermostability of free (a) and immobilized (b) C. viswanathii lipase. Lipase activity was determined in McIlvaine buffer $\mathrm{pH} 4.0$ at $45^{\circ} \mathrm{C}$. Free enzyme was incubated up to $60 \mathrm{~min}$ and derivative was incubated up to $180 \mathrm{~min}$. Free lipase activity corresponded to $36.0 \mathrm{U} / \mathrm{mg}$ prot. and immobilized lipase corresponded to $38.0 \mathrm{U} / \mathrm{mg}$ prot.

preparation, followed by butyl Sepharose, while either butyl or hexyl Toyopearl preparations presented low stabilities.

\subsubsection{Effect of ions and different chemical compounds}

The effect of ions and substances on free and immobilized lipase is shown in Table 2. Among metal ions, $\mathrm{Mn}^{+2}, \mathrm{Mg}^{+2}$ and $\mathrm{Zn}^{+2}$ slightly activated the free enzyme, but only $\mathrm{Mn}^{+2}$ activated the immobilized lipase. $\mathrm{Mg}^{+2}$ and $\mathrm{Ca}^{+2}$ are well known activators of lipases because these metal ions form complexes with ionized fatty acids which may facilitate their removal in reactions at the water-oil interface, changing their stability and behavior [33].

$\mathrm{Co}^{+2}$ had inhibitory effect at $10 \mathrm{mM}$ for both free and immobilized lipase. The free lipase activity was strongly inhibited by $\mathrm{Cu}^{+2}$ at $10 \mathrm{mM}$, but the immobilized lipase was not affected by this ion, whereas, $\mathrm{Hg}^{+2}$ moderately and strongly inhibited the free and the immobilized enzyme, respectively. Possibly, the active site of the immobilized enzyme is more exposed and therefore more sensitive to $\mathrm{Hg}^{+2}$. Inhibition by $\mathrm{Hg}^{+2}$ was also observed for lipases from Mucor sp. [34] and Penicillium sp. DS-39 [35] at 1-20 mM. These results suggest the presence of thiol groups of cysteine close or in the active site. The active site of several lipases consists of the catalytic triad Ser (nucleophile)-Asp/Glu (acid)-His, similar to those from serine proteases; the triad residues are variable and Cys was identified as the nucleophile, which can modulate conformational changes of lipase interfaces and may be involved in substrate recognition [36]. 1,4-dithiothreitol (DTT) and $\beta$-mercaptoethanol slightly increased the activity of both free and immobilized lipase at $10 \mathrm{mM}$. These results confirm the structural or functional importance of cysteine for the enzyme, what may be explained by preventing oxidation of thiol groups [37]. These reducing thiol agents also act decreasing the activity of enzymes that have disulfide bonds, disassembling the three-dimensional protein structure. Usually, these agents did not influence the activity of lipases, suggesting that there are small quantities of cysteine or cystine in these enzymes, or even that these amino acids have little relationship to their activities [33,38-40]. Exceptionally, activation with $\beta$-mercaptoethanol is also observed for the lipases from Burkholderia sp. HY-10 [41] and Metarhizium anisopliae [42], whereas activating effect by DTT was observed for the Candida deformans lipase [43].

Ethylenediaminetetraacetic acid (EDTA) moderately inhibited the free enzyme at 2 and $10 \mathrm{mM}$, however, this effect was not observed for the immobilized enzyme. Chelation of divalent ions by EDTA has important influence in the formation of the enzyme-substrate complex for metalloenzymes that require these ions for activity. These results suggest that the conformation of the free $C$. viswanathii lipase may be modulated by cations and the immobilization could stabilize the active conformation, preventing loss of activity or of the ion when incubated with EDTA. This effect is also observed for the Pseudozyma hubeiensis lipase, in which EDTA reduces the activity of the free enzyme by $45 \%$ and had no effect on the immobilized form [44]. Some studies also report inhibition by EDTA for the lipases from Burkholderia multivorans [45] and Pseudomonas gessardii [40], suggesting that they are metalloenzymes.

Phenylmethylsulfonyl fluoride (PMSF) showed moderate and pronounced inhibitory effect at 2 and $10 \mathrm{mM}$, respectively, for both free and immobilized enzyme. PMSF inhibits enzymes containing serine and cysteine residues in the active site, such as some proteases [46], suggesting that $C$. viswanathii lipase can be a serine or cysteine hydrolase. Inhibition by PMSF is also observed for several other microbial lipases [37,45,47-49]. Nam et al. [39] studied the inhibitory effect of PMSF on microbial lipases using X-ray crystallography. These authors found that the serine residue of the catalytic triad and the sulfonyl center of PMSF form a covalent bond, being the structural configuration of this complex similar to that from serine proteases.

The anionic SDS detergent resulted in complete activity loss of both free and immobilized lipase, because SDS binds and denature hydrophobic regions. Non-ionic detergents such as Tween 80 and Tween 20 and anionic detergent such as sodium deoxycholate decreased the activity of both free and immobilized lipase. In many cases, anionic detergents negatively affect lipase activity; and this effect can be associated with repulsion of protein molecules from the substrate interface [50]. According to Guncheva and Zhiryakova [49] surfactants at high concentrations have negative effect on lipase activity probably because they block substrate access to the active site. Exceptionally, the purified lipase from B. multivorans is activated by SDS, Triton X-100, Tween 80 at $0.1 \%$ and sodium deoxycholate, what can be attributed to a change in enzyme structure resulting in increased substrate accessibility [45].

Stability of free and immobilized lipase were also evaluated in these same chemical compounds at 2 and $10 \mathrm{mM}$. High stabilities of free enzyme were observed with $\mathrm{Co}^{+2}, \mathrm{DTT}, \mathrm{Na}^{+}, \mathrm{PMSF}, \mathrm{Mg}^{+2}$, EDTA, $\mathrm{Hg}^{+2}, \mathrm{Ba}^{+2}$ and $\mathrm{Ca}^{+2}$ at $2 \mathrm{mM}$. At $10 \mathrm{mM}$, high stabilities were observed with $\mathrm{Mn}^{+2}, \mathrm{NH}_{4}{ }^{+}, \mathrm{Na}^{+}$and DTT, respectively. For immobilized lipase, it was observed high stability with $\mathrm{NH}_{4}{ }^{+}, \mathrm{PMSF}, \mathrm{Co}^{+2}$, EDTA, $\beta$ mercaptoethanol, Tween 20 and DTT, at $2 \mathrm{mM}$, respectively; and at $10 \mathrm{mM}$, with $\mathrm{Ca}^{+2}, \mathrm{Mn}^{+}, \mathrm{Hg}^{+2}, \mathrm{Co}^{+2}, \mathrm{Cu}^{+2}$, Tween 20 , respectively. The immobilization of lipase improved the stability in the presence of the majority of ions. These results can be used to improve the operational conditions in enzymatic process.

\subsubsection{Effect of organic solvents}

Table 3 shows the effect of organic solvents on the stability of free 
Table 2

Effect of ions and other chemical compounds on free and immobilized lipase from C. viswanathii.

\begin{tabular}{|c|c|c|c|c|c|c|c|c|}
\hline \multirow[t]{3}{*}{ Substances } & \multicolumn{4}{|l|}{$2 \mathrm{mM}$} & \multicolumn{4}{|l|}{$10 \mathrm{mM}$} \\
\hline & \multicolumn{2}{|l|}{ Free Enzyme } & \multicolumn{2}{|l|}{ Immobilized enzyme } & \multicolumn{2}{|l|}{ Free Enzyme } & \multicolumn{2}{|l|}{ Immobilized enzyme } \\
\hline & Relative activity (\%) & $\mathrm{t}_{1 / 2}(\mathrm{~h})$ & Relative activity (\%) & $\mathrm{t}_{1 / 2}(\mathrm{~h})$ & Relative activity (\%) & $\mathrm{t}_{1 / 2}(\mathrm{~h})$ & Relative activity (\%) & $\mathrm{t}_{1 / 2}(\mathrm{~h})$ \\
\hline Control & $100.0 \pm 4.5$ & $43.3 \pm 1.2$ & $100.0 \pm 7.7$ & $43.6 \pm 2.0$ & $100.0 \pm 7.4$ & $45.6 \pm 2.1$ & $100.0 \pm 4.1$ & $46.4 \pm 1.9$ \\
\hline $\mathrm{HgCl}_{2}$ & $94.5 \pm 9.4$ & $68.4 \pm 2.1$ & $93.5 \pm 8.7$ & $32.4 \pm 1.8$ & $60.1 \pm 5.6$ & $47.6 \pm 2.5$ & $14.7 \pm 3.9$ & $71.8 \pm 3.3$ \\
\hline $\mathrm{ZnSO}_{4}$ & $96.8 \pm 8.5$ & $32.6 \pm 2.3$ & $99.4 \pm 7.9$ & $40.8 \pm 2.4$ & $112.4 \pm 3.2$ & $8.5 \pm 0.8$ & $100.4 \pm 7.8$ & $15.8 \pm 1.2$ \\
\hline $\mathrm{CuCl}_{2}$ & $91.8 \pm 10.2$ & $26.4 \pm 1.3$ & $97.6 \pm 5.2$ & $37.4 \pm 2.0$ & $3.9 \pm 5.1$ & $28.6 \pm 1.3$ & $97.6 \pm 6.9$ & $60.0 \pm 2.5$ \\
\hline $\mathrm{CoCl}_{2}$ & $96.1 \pm 11.9$ & $72.0 \pm 3.3$ & $92.4 \pm 4.7$ & $47.5 \pm 1.9$ & $50.1 \pm 5.1$ & $66.8 \pm 2.3$ & $56.3 \pm 5.2$ & $70.8 \pm 1.5$ \\
\hline $\mathrm{CaCl}_{2}$ & $101.9 \pm 11.9$ & $64.0 \pm 3.5$ & $100.0 \pm 8.9$ & $44.8 \pm 1,3$ & $101.0 \pm 9.9$ & $44.8 \pm 1.4$ & $104.4 \pm 12.2$ & $72.0 \pm 2.1$ \\
\hline $\mathrm{BaCl}_{2}$ & $107.9 \pm 3.5$ & $66.8 \pm 3.3$ & $96.2 \pm 6.3$ & $35.2 \pm 1.2$ & $100.3 \pm 6.1$ & $54.0 \pm 2.5$ & $100.3 \pm 7.7$ & $40.0 \pm 3.2$ \\
\hline $\mathrm{MnSO}_{4}$ & $113.0 \pm 5.2$ & $13.2 \pm 1.3$ & $120.9 \pm 9.4$ & $72.0 \pm 3.5$ & $108.8 \pm 8.3$ & $12.8 \pm 1.0$ & $107.2 \pm 2.8$ & $72.0 \pm 2.4$ \\
\hline $\mathrm{NaCl}$ & $103.0 \pm 8.6$ & $70.8 \pm 2.7$ & $106.4 \pm 8.0$ & $71.2 \pm 2.9$ & $102.4 \pm 7.7$ & $15.8 \pm 1.3$ & $105.3 \pm 6.3$ & $51.4 \pm 1.8$ \\
\hline $\mathrm{NH}_{4} \mathrm{Cl}$ & $103.2 \pm 5.5$ & $60.0 \pm 2.8$ & $104.9 \pm 7.0$ & $67.6 \pm 3.7$ & $102.0 \pm 8.4$ & $70.0 \pm 3.4$ & $105.6 \pm 9.7$ & $22.0 \pm 1.2$ \\
\hline $\mathrm{MgSO}_{4}$ & $117.4 \pm 8.5$ & $68.0 \pm 3.7$ & $108.2 \pm 6.2$ & $43.6 \pm 2.7$ & $101.7 \pm 7.5$ & $42.8 \pm 2.2$ & $106.9 \pm 8.9$ & $17.0 \pm 0.7$ \\
\hline $\mathrm{Pb}\left(\mathrm{CH}_{3} \mathrm{COO}\right)_{2}$ & $104.2 \pm 6.4$ & $14.4 \pm 1.1$ & $107.1 \pm 5.9$ & $39.5 \pm 2.1$ & $107.3 \pm 10.6$ & $66.0 \pm 1.3$ & $104.9 \pm 10.3$ & $62.0 \pm 3.1$ \\
\hline EDTA & $71.0 \pm 7.6$ & $71.6 \pm 3.4$ & $93.6 \pm 6.4$ & $36.0 \pm 1.3$ & $61.1 \pm 2.8$ & $67.2 \pm 2.1$ & $106.0 \pm 7.8$ & $44.8 \pm 2.1$ \\
\hline DTT & $104.9 \pm 10.7$ & $72.0 \pm 2.8$ & $99.0 \pm 2.7$ & $66.5 \pm 3.3$ & $119.3 \pm 9.5$ & $54.4 \pm 1.8$ & $124.3 \pm 3.6$ & $29.4 \pm 1.1$ \\
\hline$\beta$-mercaptoethanol & $97.0 \pm 8.7$ & $56.0 \pm 1.4$ & $98.62 \pm 4.7$ & $38.0 \pm 1.7$ & $113.1 \pm 5.8$ & $66.2 \pm 3.6$ & $134.1 \pm 10.8$ & $43.2 \pm 2.1$ \\
\hline PMSF & $89.8 \pm 7.7$ & $70.0 \pm 2.2$ & $89.0 \pm 0.89$ & $41.2 \pm 1.2$ & $20.5 \pm 9.2$ & $66.8 \pm 2.7$ & $23.4 \pm 2.8$ & $10.0 \pm 0.8$ \\
\hline Tween 20 & $77.6 \pm 9.4$ & $56.8 \pm 2.9$ & $68.1 \pm 5.1$ & $14.0 \pm 1.0$ & $45.5 \pm 5.2$ & $65.8 \pm 2.1$ & $34.3 \pm 7.8$ & $59.2 \pm 1.3$ \\
\hline Tween 80 & $59.5 \pm 6.6$ & $45.6 \pm 2.0$ & $52.6 \pm 2.4$ & $24.0 \pm 1.2$ & $32.4 \pm 8.8$ & $20.2 \pm 0.9$ & $22.4 \pm 2.8$ & $21.8 \pm 1.1$ \\
\hline SDS & ND & ND & ND & ND & ND & ND & ND & ND \\
\hline Sodium deoxycholate & $80.3 \pm 4.7$ & $46.8 \pm 1.9$ & $89.5 \pm 5.5$ & $28.8 \pm 1.1$ & $81.8 \pm 8.6$ & $13.4 \pm 1.2$ & $93.7 \pm 1.8$ & $36.0 \pm 2.1$ \\
\hline
\end{tabular}

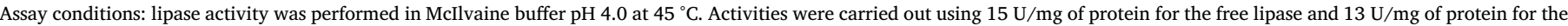

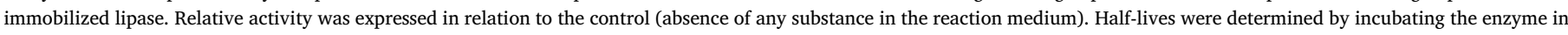

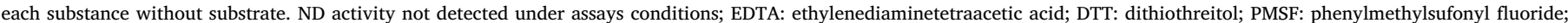
SDS: sodium dodecyl sulfate.

and immobilized C. viswanathii lipase. Solvents are listed according to their hydrophobicity ( $\log P$ ) ranging from -1.67 to 4.51 and according to its polarity $\mathrm{E}_{\mathrm{T}}(30)$. Negative hydrophobicity $(\log P$ ) values indicate that the solvent is water soluble, whereas positive values indicate they are insoluble, occurring separation of the aqueous from the organic phase [51]. The $\mathrm{E}_{\mathrm{T}}(30)$ is defined as the molar transition energies (kcal mol ${ }^{-1}$ ) of the standard betaine dye [52]. High $\mathrm{E}_{\mathrm{T}}(30)$ values correspond to high solvent polarity. Lipases have different sensitivity to solvents, but in general, water-miscible polar solvents are more destabilizing than water-immiscible solvents [48]. Non-polar solvents probably promote changes in the equilibrium between the open and closed conformation of lipases and also modify solubility of substrates and reaction products; while polar solvents are more destabilizing to the protein structure by removing the solvation water $[38,49]$. Under these conditions, activation and inactivation of lipases was observed using non-polar or polar organic solvents. Enzyme inactivation might be due to the relatively high viscosity of the solvents, which hindered efficient interaction between the enzymes and substrates; on the other hand, the activation of lipase in the presence of some water-miscible organic solvents can be explained possibly by the disruption of aggregates formed by enzyme molecules [53].

Nevertheless, no correlation between $\log P$ and $\mathrm{E}_{\mathrm{T}}(30)$ values of solvents with relative stability was observed for the $C$. viswanathii lipase. The enzyme was very stable in most of them, retaining more than $80 \%$ of activity for both free and immobilized enzyme, except for the free enzyme in xylol, for the immobilized form in methanol and

Table 3

Effect of organic solvents on free and immobilized lipase from C. viswanathii.

\begin{tabular}{|c|c|c|c|c|c|c|}
\hline \multirow[t]{2}{*}{ Organic solvents } & \multirow[t]{2}{*}{$\log P$} & \multirow[t]{2}{*}{ Et(30) $\left(\mathrm{kcal} \mathrm{mol}^{-1}\right)$} & \multicolumn{2}{|l|}{ Free lipase } & \multicolumn{2}{|l|}{ Immobilized lipase } \\
\hline & & & Relative activity (\%) & $\mathrm{t}_{1 / 2}(\mathrm{~h})$ & Relative activity (\%) & $\mathrm{t}_{1 / 2}(\mathrm{~h})$ \\
\hline Control & & & $100.0 \pm 4.1$ & $16.8 \pm 0.3$ & $100.0 \pm 4.6$ & $46.4 \pm 2.1$ \\
\hline Glycerol & -1.67 & 57.9 & $110.4 \pm 5.7$ & $36.0 \pm 1.2$ & $139.3 \pm 2.4$ & $45.2 \pm 1.9$ \\
\hline DMSO & -1.38 & 45.1 & $108.5 \pm 2.5$ & $31.2 \pm 0.9$ & $159.3 \pm 2.9$ & $42.0 \pm 2.5$ \\
\hline Propylene glycol & -0.92 & - & $90.5 \pm 7.7$ & $23.2 \pm 1.1$ & $176.1 \pm 6.8$ & $40.0 \pm 1.8$ \\
\hline Methanol & -0.76 & 55.4 & $104.1 \pm 7.5$ & $16.4 \pm 0.4$ & $63.0 \pm 7.0$ & $37.2 \pm 2.1$ \\
\hline Acetonitrile & -0.40 & 45.6 & $86.6 \pm 8.2$ & $14.2 \pm 0.3$ & $118.4 \pm 10.5$ & $42.4 \pm 1.6$ \\
\hline Ethanol & -0.24 & 51.9 & $116.7 \pm 6.1$ & $17.6 \pm 0.7$ & $82.2 \pm 1.9$ & $36.4 \pm 1.4$ \\
\hline Acetone & -0.23 & 42.2 & $81.8 \pm 6.8$ & $17.2 \pm 0.2$ & $73.4 \pm 10.9$ & $38.1 \pm 0.9$ \\
\hline 2-propanol & 0.07 & 48.6 & $101.5 \pm 9.8$ & $18.0 \pm 0,9$ & $126.8 \pm 1.0$ & $39.4 \pm 1.3$ \\
\hline 1-propanol & 0.25 & 50.7 & $87.0 \pm 4.3$ & $15.2 \pm 0.8$ & $167.5 \pm 7.3$ & $22.0 \pm 0.3$ \\
\hline n-butanol & 0.80 & 49.7 & $88.0 \pm 9.9$ & $30.4 \pm 1.3$ & $107.8 \pm 5.0$ & $14.3 \pm 0.8$ \\
\hline Toluene & 2.50 & 33.9 & $72.2 \pm 5.3$ & $15.0 \pm 0.7$ & $62.0 \pm 4.0$ & $30.8 \pm 1.6$ \\
\hline Xylol & 3.15 & 34.7 & $78.0 \pm 7.4$ & $49.2 \pm 2.1$ & $139.9 \pm 1.5$ & $27.0 \pm 0.9$ \\
\hline$n$-Hexane & 3.50 & 30.9 & $86.5 \pm 8.5$ & $40.4 \pm 2.3$ & $120.0 \pm 10.7$ & $30.4 \pm 1.9$ \\
\hline Iso-octane & 4.51 & 30.9 & $98.4 \pm 7.8$ & $24.8 \pm 0.2$ & $135.9 \pm 7.4$ & $42.1 \pm 3.1$ \\
\hline
\end{tabular}

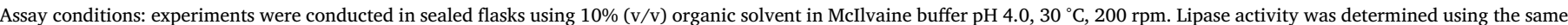

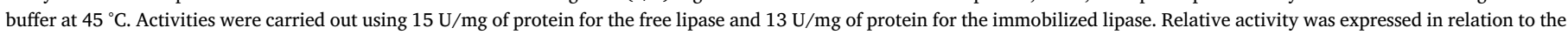

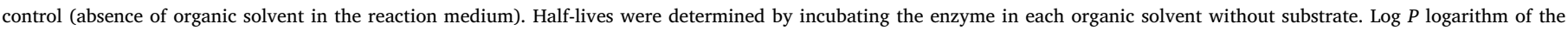
partition coefficient of a particular solvent $n$-octanol and water (Sangster, 1989). 
acetone, and for both forms in toluene. This important characteristic enables various industrial applications as transesterification reactions, synthesis and resolution of racemic esters [45]. Half-lives of the immobilized lipase were more than $40 \mathrm{~h}$ using glycerol, DMSO, propylene glycol, acetonitrile, and isooctane. Intermediate half-lives were observed with methanol, ethanol, acetone, 2-propanol, 1-propanol, toluene, xylol, and $n$-hexane, while the shortest half-life was observed with $n$-butanol. On the other hand, the free lipase presented shorter half-lives in most solvents. Prolonged half-lives were observed only with xylol and $n$-hexane; intermediate values were verified with glycerol, DMSO, propylene glycol, $n$-butanol, and isooctane; and the shorter values with methanol, acetonitrile, ethanol, acetone, 2-propanol, 1-propanol and toluene.

The activity of the free enzyme was slightly stimulated after $1 \mathrm{~h}$ incubation with ethanol, glycerol and DMSO (117, 110 and 108\%, respectively). Methanol, 2-propanol and isooctane did not affect enzyme activity. The results obtained with the free lipase from $C$. viswanathii were similar to the lipases from Rhizopus homothallicus var. rhizopodiformis, Aspergillus niger MYA 135 [54] in organic solvents, which also show no correlation between stability and $\log P$ values [55].

The immobilized enzyme was moderately stimulated in the presence of xylol, glycerol, isooctane, 2-propanol, $n$-hexane and acetonitrile, and stronger activations were found with propylene glycol (176.1\%), 1propanol (167.7\%), and DMSO (159.3\%). Butanol did not affect enzyme activity, while in methanol and ethanol stability was lower for the immobilized form than for the free enzyme.

\subsubsection{Specificity for substrate}

Hydrolytic activity of free and immobilized lipase was evaluated on p-nitrophenyl ester substrates (Fig. 7a). The activity increased by increasing ester chains of fatty acids up to $p$-nitrophenyl palmitate. Lower levels of activity were observed from acetate to myristate and stearate for both free and immobilized enzyme. The lipase specificity for longchain hydrophobic substrates can be attributed to the geometry, size and structure of the enzyme active site [56]. Specificity for long-chain fatty acids esters has also been reported for lipases from Pseudomonas aeruginosa BN-1 [57] and Yarrowia lipolytica [58]. Other lipases present higher activity on intermediate-chain fatty acids esters such as those from Mucor sp. [34], Burkholderia sp. HY-10 [41] and Amycolatopsis mediterranei DSM 43304 [59]. On the other hand, lipases from $\mathrm{Me}$ tarhizium anisopliae [42] and C. rugosa [60] show higher specificity for short-chain fatty acids esters (C2-C8), being classified as esterase or lipases with esterase activity [61].

Both free and immobilized lipases were evaluated on the hydrolysis of triacylglycerols and phospholipid (soy lecithin) by titration of free fatty acids (Fig. 7b). Both lipase forms presented a significant preference for the pure triacylglycerol triolein that presents long-chain monounsaturated fatty acids (oleic acid) esterified in the glycerol compared to tributyrin. Among natural triacylglycerols, free and immobilized lipase presented high activity on olive oil (85 and 90\% hydrolysis, respectively), followed by soybean oil ( $~ 80 \%$ hydrolysis) and canola oil (74 and 79\% hydrolysis, respectively). Intermediate hydrolytic activity was found with sunflower oil ( $\sim 65 \%$ hydrolysis) and corn oil (50 and $60 \%$ hydrolysis, respectively). Remarkably, both free and immobilized lipases were highly active on soy lecithin $(\sim 87 \%)$ in comparison to triolein hydrolysis. Microbial lipases naturally hydrolyze plant or animal triacylglycerols, but hydrolysis of soy lecithin, a phospholipid, has been rarely verified [62]. Free and immobilized C. viswanathii lipase hydrolyzed olive oil and soy lecithin with the same efficiency, resulting in 85 and $87 \%$ hydrolysis, respectively, compared to triolein hydrolysis. High triacylglycerol hydrolysis was also observed on soybean, canola and sunflower oils. Intermediate activity was verified on corn oil, and the lowest activity was verified on tributyrin, that has the smallest chain.
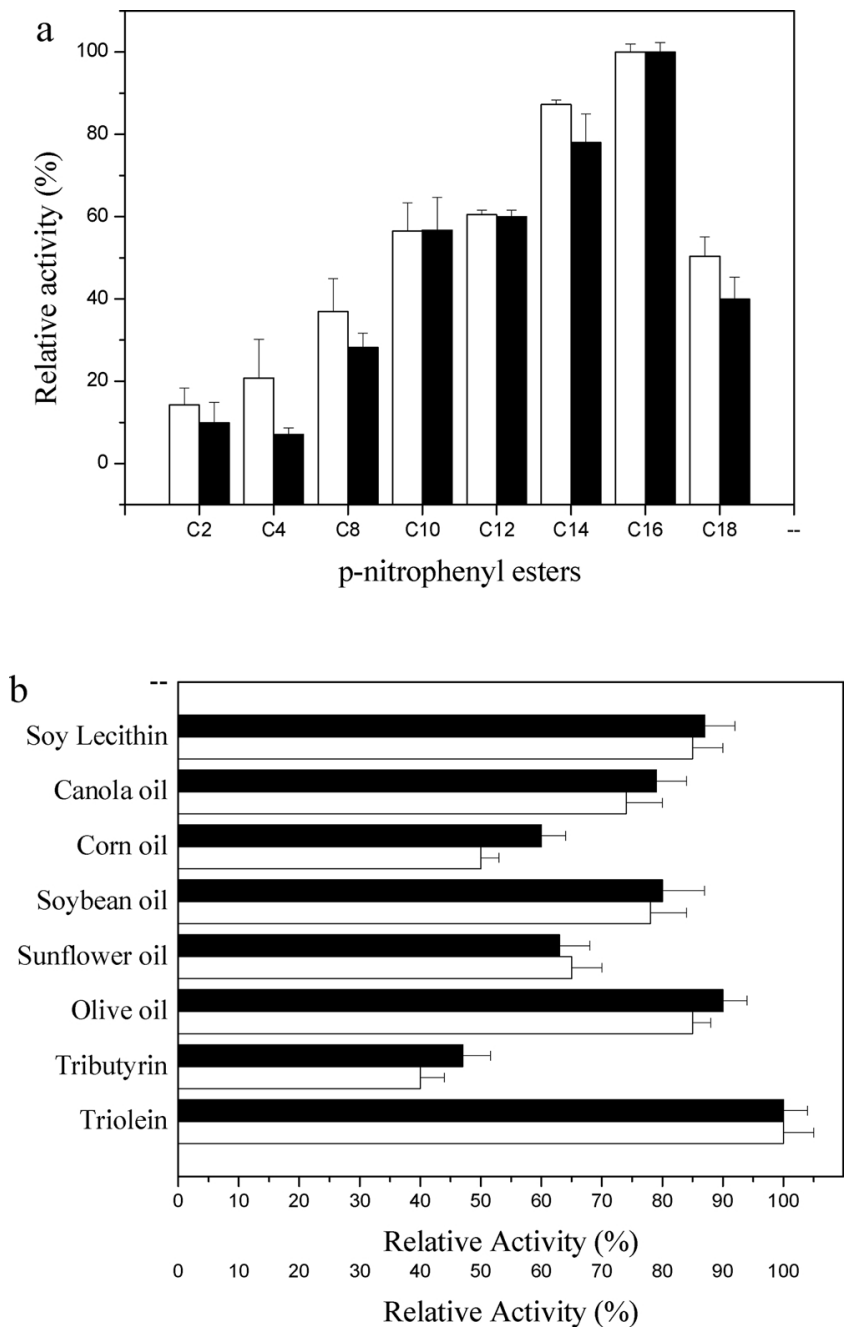

Fig. 7. Activity on p-nitrophenyl esters (a) and triacylglycerol and lecithin hydrolysis (b) of free and immobilized $C$. viswanathii lipase. Activity was determined in McIlvaine buffer $\mathrm{pH} 4.0$ at $45{ }^{\circ} \mathrm{C}$. ( $\square$ ) Free lipase, ( $\square$ ) immobilized lipase. Free lipase activity corresponded to $36.0 \mathrm{U} / \mathrm{mg}$ prot. and immobilized lipase corresponded to $38.0 \mathrm{U} / \mathrm{mg}$ prot. $\mathrm{C} 2$ acetate, C4 butirate, C8 caproate, C10 decanoate, C12 laurate, C14 myristate, C16 palmitate, $\mathrm{C} 18$ stearate.

\subsubsection{Enzyme kinetics}

Substrate hydrolysis reactions were performed for free and immobilized lipase with $p$-NPP $(0.0-1.0 \mathrm{mM})$ to determine $K_{\mathrm{m}}$ and $\mathrm{V}_{\max }$. From these values, the turnover number $\left(k_{\text {cat }}\right)$ and the catalytic efficiency $\left(k_{\mathrm{cat}} / K_{\mathrm{m}}\right)$ for the free enzyme were calculated (Table 4$)$. Free lipase showed $K_{\mathrm{m}} 0.16 \mathrm{mM}$ and $\mathrm{V}_{\max } 889.6 \mu \mathrm{mol} \mathrm{min}{ }^{-1} \mathrm{mg}$ protein ${ }^{-1}$. $K_{\mathrm{m}}$ value for the immobilized enzyme was $0.08 \mathrm{mM}$ and $\mathrm{V}_{\max }$ of $900.1 \mu$ mol.min ${ }^{-1} \mathrm{mg}$ protein ${ }^{-1}$. The hydrophobic immobilization of C. viswanathii lipase improved the catalytic properties of the immobilized enzyme, allowing increased access of the substrate to the

Table 4

Kinetic parameters of free and immobilized lipase from C. viswanathii for $p$-nitrophenyl palmitate hydrolysis.

\begin{tabular}{lllll}
\hline Enzyme form & \multicolumn{5}{l}{ Parameter } & & \\
\cline { 2 - 5 } & $K_{\mathrm{m}}(\mathrm{mM})$ & $\begin{array}{l}\mathrm{V}_{\max } \\
\left(\mu \mathrm{mol} \mathrm{min} \mathrm{min}^{-1} \mathrm{mg} \mathrm{prot}^{-1}\right)\end{array}$ & $k_{\text {cat }}\left(\mathrm{s}^{-1}\right)$ & $\begin{array}{l}k_{\mathrm{cat}} / K_{\mathrm{m}} \\
\left(\mathrm{M}^{-1} \mathrm{~s}^{-1}\right)\end{array}$ \\
$\begin{array}{c}\text { Free lipase } \\
\begin{array}{c}\text { Immobilized } \\
\text { lipase }\end{array}\end{array}$ & 0.16 & 889.6 & 868 & $5.4 \times 10^{6}$ \\
& 0.08 & 900.1 & - & - \\
\hline
\end{tabular}

Assay conditions: lipase activity was determined using McIlvaine buffer $\mathrm{pH} 4.0$ at $45^{\circ} \mathrm{C}$. 
catalytic site, as verified by the lower $K_{\mathrm{m}}$.

These results indicate that the hydrophobic adsorption on octyl agarose resulted in a conformational change that exposed the catalytic residues towards the solvent, making the binding site more accessible to the substrate (lower apparent $K_{\mathrm{m}}$ ). Rodrigues et al. [63] reported that in some instances, immobilization might greatly alter the physicochemical properties of the enzyme surroundings, which can produce some partition of different compounds away or towards the enzyme. If a partition of the substrates or products is achieved after immobilization, this may affect enzyme activity depending on the different possibilities of the enzymatic kinetics.

Changes in kinetic parameters obtained for the immobilized lipase from $C$. viswanathii in relation to the free enzyme were similar to those from other lipases immobilized on the same support. According to Fernandez-Lafuente et al. [64] and Palomo et al. [10], the large pocket around the active site of the open structure of lipases is strongly adsorbed on octyl-agarose even at low ionic strength, suggesting that this adsorption promotes hyperactivation of lipases. $k_{\text {cat }}$ values and catalytic efficiency for the free $C$. viswanathii lipase were $868 \mathrm{~s}^{-1}$ and $5.4 \times 10^{6} \mathrm{M}^{-1} \mathrm{~s}^{-1}$, respectively. Purified lipases A and B from C. cylindracea present $k_{\mathrm{cat}}$ values of 1010 and $1600 \mathrm{~s}^{-1}$ and $k_{\mathrm{cat}} / K_{\mathrm{m}}$ $2.5 \times 10^{7}$ and $0.42 \times 10^{7} \mathrm{M}^{-1} \mathrm{~s}^{-1}$, respectively, using $p$-nitrophenyl butyrate as substrate [13].

\section{Concluding remarks}

This work relates the purification, immobilization and a broad biochemical characterization of the $C$. viswanathii lipase produced under submerged culture conditions and its immobilized derivative. The high enzyme hydrophobicity allowed the purification to be carried out with octyl agarose using low ionic strength, resulting in a fast and relatively inexpensive one-step purification strategy. This property also allowed the lipase immobilization on the same support, giving rise to a hyperactivated derivative, which was stabilized in relation to $\mathrm{pH}$, temperature and organic solvents. Immobilization also improved the catalytic properties of the immobilized enzyme, shown by the $K_{\mathrm{m}}$ decrease.

In contrast to other Candida lipases, the free $C$. viswanathii lipase and its derivative present high activity and stability in more acid $\mathrm{pH}$, what can be considered interesting for application in process such as acid bating of fur and wool, and also in the composition of digestive aids for medical treatment. Besides, the tolerance to organic solvents, the stability during several re-use cycles and the ability to hydrolyze triacylglycerols and phospholipid indicate high potential application in food and pharma industries, as well as for chemical synthesis.

\section{Acknowledgements}

The authors would like to thank the National Council of Technological and Scientific Development (CNPq) for financial support (Process number 455754/2014-4), and to Mr. Anderson Rodrigues for technical assistance.

\section{References}

[1] K. Ramani, S. Karthikeyan, R. Boopathy, L.J. Kennedy, A.B. Mandal, G. Sekaran, Surface functionalized mesoporous activated carbon for the immobilization of acidic lipase and their application to hydrolysis of waste cooked oil: isotherm and kinetic studies, Process Biochem. 47 (2012) 435-445.

[2] F. Hasan, A.A. Shah, A. Hameed, Industrial applications of microbial lipases, Enzyme Microb. Technol. 39 (2006) 235-251.

[3] K. Sharma, M. Rathore, Comparative evaluation of specific activity of crude and partially purified lipase preparation from lipolytic bacteria, Int. J. Pharm. Sci. Res. 1 (2010) 31-38.

[4] E.A. Manoel, J.C.S. Santos, D.M.G. Freire, N. Rueda, R. Fernandez-Lafuente Immobilization of lipases on hydrophobic supports involves the open form of the enzyme, Enzyme Microb. Technol. 71 (2015) 53-57.

[5] E.A. Snellman, R.R. Colwell, Acinetobacter lipases: molecular biology, biochemical properties and biotechnological potential, J. Ind. Microb. Biotechnol. 31 (2004)
$391-400$

[6] A. Pandey, S. Benjamin, C.R. Soccol, P. Nigam, N. Krieger, V.T. Soccol, The realm of microbial lipases in biotechnology, Biotechnol. Appl. Biochem. 29 (2) (1999) 119-131.

[7] D.H. Zhang, L.X. Yuwen, L.J. Peng, Parameters affecting the performance of immobilized enzyme, J. Chem. (2013).

[8] M.W. Christensen, L. Andersen, T.L. Husum, O. Kirk, Industrial lipase immobilization, Eur. J. Lipid Sci. Technol. 105 (2003) 318-321.

[9] A. Bastida, P. Sabuquillo, P. Armisen, R. Fernández-Lafuente, J. Huguet, J.M. Guisán, A single step purification, immobilization, and hyperactivation of lipases via interfacial adsorption on strongly hydrophobic supports, Biotechnol. Bioeng. 58 (5) (1998) 486-493.

[10] J.M. Palomo, G. Munoz, G. Fernández-Lorente, C. Mateo, R. Fernández-Lafuente, J.M. Guisán, Interfacial adsorption of lipases on very hydrophobic support (octadecyl-Sepabeads): immobilization, hyperactivation and stabilization of the open form of lipases, J. Mol. Catal. B Enzym. 19-20 (2002) 279-286.

[11] R. Verger, Interfacial activation of lipases: facts and artifacts, TibTech 15 (1997) $32-38$

[12] A. Aloulou, J.A. Rodriguez, S. Fernandez, D. van Oosterhout, D. Puccinelli, F. Carrière, Exploring the specific features of interfacial enzymology based on lipase studies, Biochim. Biophys. Acta 176 (2006) 995-1013.

[13] M.L. Rúa, T. Diaz-Maurino, V.M. Fernández, C. Otero, A. Ballesteros, Purification and characterization of two distinct lipases from Candida cylindracea, Biochim. Biophys. Acta 1156 (1993) 181-189.

[14] M.A. Pernas, C. López, L. Pastrana, M.L. Rúa, Purification and characterization of Lip2 and Lip3 isoenzymes from a Candida rugosa pilot-plant scale fed-batch fermentation, J. Biotechnol. 84 (2000) 163-174.

[15] A. Dimitrijevic, D. Velickovic, F. Bihelovic, D. Bezbradica, R. Jankov, N. Milosavic, One-step, inexpensive high yield strategy for Candida antarctica lipase A isolation using hydroxyapatite, Bioresour. Technol. 107 (2012) 358-362.

[16] H. Yao, T. Zhanga, H. Xue, K. Tanga, R. Li, Biomimetic affinity purification of Candida antarctica lipase B, J. Chromatogr. B 879 (2011) 3896-3900.

[17] J.M. Palomo, M.M. Penas, G. Fernández-Lorente, C. Mateo, A.G. Pisabarro, R.L. Fernández-Lafuente, J.M. Guisán, Solid-phase handling of hydrophobins: immobilized hydrophobins as a new tool to study lipases, Biomacromolecules 4 (2003) 204-210.

[18] M.Y. Arica, H. Soydogan, G. Bayramoglu, Reversible immobilization of Candida rugosa lipase on fibrous polymer grafted and sulfonated p(HEMA/EGDMA) beads, Bioprocess Biosyst. Eng. 33 (2010) 227-236.

[19] A.F. Almeid, S.M. Tauk-Tornisielo, E.C. Carmona, Influence of carbon and nitrogen sources on lipase production by a newly isolated Candida viswanathii strain, Annals Microbiol. 63 (4) (2012) 1225-1234.

[20] A.F. Almeida, S.M. Tauk-Tornisielo, E.C. Carmona, Acid lipase from Candida viswanathii: production, biochemical properties, and potential application, Biomed. Res. (2013).

[21] H.J. Vogel, A convenient growth medium for Neurospora crassa (medium N), Microbiol. Gen. Bul. 13 (1956) 42-43.

[22] P.K. Smith, R.I. Krohn, G.T. Hermanson, A.K. Mallia, F.H. Gartener, M.D. Provenzano, E.K. Fujimoto, N.M. Goeke, B.J. Olson, D.C. Klenk, Measurement of protein using bicinchoninic acid, Anal. Biochem. 150 (1985) 76-85.

[23] B.D. Hames, An Introduction to polyacrylamide gel electrophoresis, in: B.D. Hames D. Rickwood (Eds.), Gel Electrophoresis of Proteins: A Practical Approach, IRL Press, Oxford, 1987, pp. 1-91 (6th reprinting).

[24] E. Lesuisse, K. Schanck, C. Colson, Purification and preliminary characterization of the extracellular lipase of Bacillus subtilis168, an extremely basic pH-tolerant enzyme, Eur. J. Biochem. 216 (1993) 155-160.

[25] H. Lineweaver, D. Burk, The determination of the enzyme dissociation, J. Am. Chem. Soc. 56 (1934) 658-666.

[26] R.P. Hughey, N.P. Curthoys, Comparison of the size and physical properties of $\gamma$ glutamyltranspeptidase purified from rat kidney following solubilization with papain or with triton x-100, J. Biol. Chem. 251 (24) (1976) 7863-7870.

[27] G. Fernández-Lorente, J.M. Palomo, M. Fuentes, C. Mateo, J.M. Guisan, R. Fernandez-Lafuente, Self-Assembly of Pseudomonas fluorescens lipase into bimolecular aggregates dramatically affects functional properties, Biotechnol. Bioeng. 82 (2) (2003)

[28] Y.C. Liou, A.G. Marangoni, R.Y. Yada, Aggregation behavior of Candida rugosa lipase, Food Res. Int. 31 (3) (1998) 243-248.

[29] Z. Guo, A.F. Vikbjerg, X. Xu, Enzymatic modification of phospholipids for functional applications and human nutrition, Biotechnol. Adv. 23 (2005) 203-259.

[30] H. Ghamgui, N. Miled, M. Karra-Cha, Y. Gargouri, Immobilization studies and biochemical properties of free and immobilized Rhizopus oryzae lipase onto $\mathrm{CaCO} 3$ : A comparative study, Biochem. Eng. J. 37 (2007) 34-41.

[31] L. Wilson, J.M. Palomo, G. Fernández-Lorente, A. Illanes, J.M. Guisán, R. Fernández-Lafuente, Improvement of the functional properties of a thermostable lipase from Alcaligenes sp: via strong adsorption on hydrophobic supports, Enzyme Microb. Technol. 38 (2006) 975-980.

[32] G. Fernandez-Lorente, Z. Cabrera, C. Godoy, R. Fernandez-Lafuente, J.M. Palomo, J.M. Guisan, Interfacially activated lipases against hydrophobic supports: effect of the support nature on the biocatalytic properties, Process Biochem. 43 (2008) 1061-1067.

[33] M. Yu, S. Lange, S. Richter, T. Tan, R.D. Schmid, High-level expression of extracellular lipase Lip2 from Yarrowia lipolytica in Pichia pastoris and its purification and characterization, Protein Expres. Purif. 53 (2007) 255-263.

[34] H. Abbas, A. Hiol, V. Deyris, L. Comeau, Isolation and characterization of an extracellular lipase from Mucor sp strain isolated from palm fruit, Enzyme Microb. Technol. 31 (2002) 968-975. 
[35] D.S. Dheeman, S. Antony-Babub, J.M. Frías, G.T.M. Henehana, Purification and characterization of an extracellular lipase from a novel strain Penicillium sp. DS-39 DSM 23773, J. Mol. Catal. B Enzym. 72 (2011) 256-262.

[36] V. Bendikiene, B. Surinemaite, B. Juodka, M. Safarikova, Insights into catalytic action mechanism of Pseudomonas mendocina 3121-1 lipase, Enzyme Microb. Technol. 34 (2004) 572-577.

[37] R.K. Scopes, Protein Purification: Principles and Practice, Springer-Verlag, New York, 1994 (P. 380).

[38] L.D. Castro-Ochoa, C. Rodríguez-Gómez, G. Valerio-Alfaro, R.O. Ros, Screening, purification and characterization of the thermoalkalophilic lipase produced by Bacillus thermoleovorans CCR11, Enzyme Microb. Technol. 37 (2005) 648-654.

[39] K.H. Nam, S.J. Kim, A. Priyadarshi, S.K. Kim, K.Y. Hwang, The crystal structure of an HSL-homolog EstE5 complex with PMSF reveals a unique configuration that inhibits the nucleophile Ser144 in catalytic triads, Biochem. Biophys. Res. Commun. 389 (2009) 247-250.

[40] K. Ramani, E. Chockalingam, G. Sekaran, Production of a novel extracellular acidic lipase from Pseudomonas gessardii using slaughterhouse waste as a substrate, J. Indian Microbiol. Biotechnol. 37 (2010) 531-535.

[41] D.S. Park, H.W. Oh, S.Y. Heo, W.J. Jeong, D.H. Shin, K.S. Bae, H.Y. Park, Characterization of an extracellular lipase in Burkholderia sp: HY-10 isolated from a longicorn beetle, J. Microbiol. 45 (5) (2007) 409-417.

[42] W.O.B. Silva, O. Santi, M. Berger, A.F.M. Pinto, J.A. Guimarães, A. Schrank, M.A. Vainstein, Characterization of a spore surface lipase from the biocontrol agent Metarhizium anisopliae, Process Biochem. 44 (2008) 829-834.

[43] O. Boutur, E. Dubreucq, P. Galzy, Factors influencing ester synthesis catalysed in aqueous media by the lipase from Candida deforrnans (Zach) Langeron and Guerra, J. Biotechnol. 42 (1995) 23-33.

[44] R. Bussamara, L. Dall'Agnol, A. Schrank, K.F. Fernandes, M.H. Vainstein, Optima conditions for continuous immobilization of pseudozyma hubeiensis (strain hb85a) lipase by adsorption in a packed-bed reactor by response surface methodology, Enzyme Res. 2012 (2012), http://dx.doi.org/10.1155/2012/329178.

[45] V. Dandavate, J. Jinjala, H. Keharia, D. Madamwar, Production, partial purification and characterization of organic solvent tolerant lipase from Burkholderia multivorans V2 and its application for ester synthesis, Bioresour. Technol. 100 (2009) 3374-3381.

[46] A.J. Barret, Classification of peptidases, Methods Enzymol. 244 (1994) 1-15.

[47] N. Nawani, N.S. Dosanjh, J. Kaur, A novel thermostable lipase from a thermophilic Bacillus sp.: characterization and esterification studies, Biotechnol. Lett. 20 (10) (1998) 997-1000.

[48] N. Nawanii, N.S. Dosanjh, J. Kaur, A thermostable lipolytic enzyme from a thermophilic Bacillus sp: : Purification and characterization, Mol. Cell. Biochem. 290
(2006) 17-22.

[49] M. Guncheva, D. Zhiryakova, Catalytic properties and potential applications of Bacillus lipases, J. Mol. Catal. B Enzym. 68 (2011) 1-21.

[50] R.P. Yadav, R.K. Saxena, R. Gupta, S. Davidson, Lipase production by Aspergillus and Penicillium species, Folia Microbiol. 43 (4) (1998) 373-378.

[51] J. Sangster, Octanol-water partition coefficients of simple organic compounds, J. Phys. Chem. 18 (3) (1989) 1111-1227.

[52] C. Reichardt, Empirical parameters of solvent polarity as linear free-energy relationships, Angew Chem. 18 (1979) 98-110.

[53] A. Kumar, K. Dhar, S.S. Kanwar, P.K. Arora, Lipase catalysis in organic solvents: advantages and applications, Biol. Proced. Online 18 (2016) 2.

[54] C.M. Romero, L.M. Pera, F. Loto, C. Vallejos, G. Castro, M.D. Baigori, Purification of an organic solvent-tolerant lipase from Aspergillus niger MYA 135 and its application in ester synthesis, Biocatal. Agric. Biotechnol. 1 (2012) 25-31.

[55] B. Hernández-Rodríguez, J. Córdova, E. Bárzana, E. Favela-Torres, Effects of organic solvents on activity and stability of lipases produced by thermotolerant fungi in solid-state fermentation, J. Mol. Catal. B Enzym. 61 (2009) 136-142.

[56] J. Pleiss, M. Fischer, R.D. Schmid, Anatomy of lipase binding sites: the scissile fatty acid binding site, Chem. Phys. Lipids 93 (1993) 67-80.

[57] Q. Ji, S. Xiao, B. He, X. Liu, Purification and characterization of an organic solventtolerant lipase from Pseudomonas aeruginosa LX1 and its application for biodiesel production, J. Mol. Catal. B Enzym. 66 (2010) 264-269.

[58] M. Yu, S. Qin, T. Tan, Purification and characterization of the extracellular lipase Lip2 from Yarrowia lipolytica, Process Biochem. 42 (2007) 384-391.

[59] D.S. Dheeman, G.T.M. Henehan, J.M. Frías, Purification and properties of Amycolatopsis mediterranei DSM 43304 lipase and its potential in flavour ester synthesis, Bioresour. Technol. 102 (2011) 3373-3379.

[60] L.C. Lee, C.C. Yen, C.C. Malmis, L.F. Chen, J.C. Chen, G.C. Lee, J.F. Shaw, Characterization of condo-optimized recombinant Candida rugosa lipase 5 (LIP 5), J. Agr. Food Chem. 59 (2011) 10693-10698.

[61] D.B. Lopes, L.P. Fraga, L.F. Fleuri, G.A. Macedo, Lipase and esterase - to what extent can this classification be applied accurately? Ciênc Tecnol Alim 31 (2011) 608-613.

[62] Z. Guo, A.F. Vikbjerg, X. Xu, Enzymatic modification of phospholipids for functional applications and human nutrition, Biotechnol. Adv. 23 (2005) 203-259.

[63] R.C. Rodrigues, C. Ortiz, A. Berenguer-Murcia, R. Torres, R. Fernández-Lafuente, Modifying enzyme activity and selectivity by immobilization, Chem. Soc. Rev. 42 (2013) 6290-6307.

[64] R. Fernandez-Lafuente, P. Armisén, P. Sabuquillo, G. Fernández-Lorente, J.M. Guisán, Immobilization of lipases by selective adsorption on hydrophobic supports, Chem. Phys. Lipids 93 (1998) 185-197. 